\title{
Fate and risks of potentially toxic elements in wastewater-fed food production systems- the examples of Cambodia and Vietnam
}

\author{
Peter E. Holm • Helle Marcussen • Anders Dalsgaard
}

Received: 17 August 2009/Accepted: 10 November 2009 /

Published online: 2 December 2009

(C) The Author(s) 2009. This article is published with open access at Springerlink.com

\begin{abstract}
Non-treated wastewater is used for irrigation of aquatic food production systems in the peri-urban areas of the major cities in Southeast Asia. This paper complement the knowledge on agricultural soil-based crops irrigated with low quality water, by reviewing the research findings on the wastewater-fed aquatic productions with special focus on heavy metals and other potentially toxic elements (PTEs) in the production systems of Hanoi in Vietnam and Phnom Penh in Cambodia. In Hanoi, sediments in the wastewater exposed rivers of Hanoi were reported to be polluted with PTEs, in particular with Cadmium (Cd). The river sediment had a high retention capacity for PTEs which seems to prevent the transport of PTEs to the wastewater-fed production systems. In Phnom Penh, domestic and industrial wastewater is pumped into the Cheung Ek Lake located south of the city. A major part of the water spinach (Ipomoea aquatica Forssk.) consumed in the city is produced in the lake. The concentrations of some PTEs were elevated at the wastewater inlets to the lake compared to concentrations at the lake outlet and at the control site. Water spinach is by far the major vegetable produced in the wastewater-fed systems in Hanoi and Phnom Penh, but did only contain PTEs in concentrations within or slightly above the concentration range observed for water spinach grown in agricultural soil not exposed to wastewater. PTE concentration in fish grown in wastewater-fed systems in Hanoi and Phnom were low. However, mean PTE concentrations in liver and skin of some fish were high. Consumption of muscle tissue from fish produced in wastewater-fed systems in Hanoi and Phnom Penh resulted in an estimated intake of PTEs amounting to less than $9 \%$ of the tolerable intake. It was concluded, that the PTE concentrations in fish and water spinach from Hanoi and Cheung Ek Lake in Phnom Penh constituted low food safety risks for consumers.
\end{abstract}

Keywords Heavy metals $\cdot$ Low quality water $\cdot$ Cadmium $\cdot \mathrm{Cd} \cdot \mathrm{PTE} \cdot$ Polluted sediments Water spinach · Fish

P. E. Holm $(\bowtie) \cdot$ H. Marcussen

Department of Basic Sciences and Environment, Faculty of Life Sciences, University of Copenhagen, Thorvaldsensvej 40, DK-1870 Frederiksberg, Denmark

e-mail: peho@life.ku.dk

A. Dalsgaard

Department of Veterinary Disease Biology, Faculty of Life Sciences, University of Copenhagen,

Groennegaardsvej 15, DK-1870 Frederiksberg, Denmark 


\section{Wastewater-fed peri-urban aquatic food production in Southeast Asia}

Peri-urban aquatic food production and risks

The production and cultivation of aquatic plants and fish is widespread in many cities in Southeast Asia and to a lesser extent Africa and Latin America. The term "urban aquaculture" captures a broad array of activities (Leschen et al. 2005). Fish farming in or around cities varies from the relatively large-scale semi-extensive culture of fish in wastewater-fed wetlands and lagoons to the engineered intensive culture of specific fish in tanks. Aquaculture also includes the cultivation of edible aquatic plants like water spinach (Ipomoea aquatica Forssk.) and other vegetables, often using wastewater, in and on the periphery of a number of cities throughout Southeast Asia. Besides aquatic systems, wastewater is traditionally reported used in agriculture to irrigate soil-based crops like rice and different cereals, as well as a number of vegetables in both large scale and householdbased productions.

In this review, wastewater (urban wastewater) is defined as a combination of domestic effluent (black and grey water), industrial effluent, sewage from commercial establishments and institutions, including hospitals and storm water and other urban runoff. Plants typically grown in water may also be cultured in soil where fields are flooded with wastewater on a regular basis. The aquatic production systems produce fish and fresh green foodstuffs, which are consumed daily by millions of people and make up a significant part of their diet. They also provide the basis for the income and livelihoods for many urban households.

The production of foods in aquatic systems using wastewater or other types of low quality water also represents several risks to human health. Groups at risk include farmers and their families, consumers of wastewater-fed produce, and people in nearby communities. Untreated wastewater carries disease-causing organisms, toxic metals, organic compounds, and other chemicals that can have negative impacts on human health. The World Health Organization (WHO) has prepared guidelines for the use of wastewater in aquaculture (WHO 2006), which mainly focuses on pathogen-related risks, in particular bacterial pathogens and helminth parasites. The cornerstone of these guidelines is the assessment of health risks based on a combination of epidemiological studies and quantitative microbial risk assessment (QMRA). Risk assessment models have been developed mostly for pathogens, i.e. Campylobacter, rotavirus, and Cryptosporodium, and little information is provided on the fate and risks of chemicals in wastewater and produce (WHO 2006). This is partly because pathogen-associated risks are of an acute nature, e.g. diarrhea and disease outbreaks, where as chemical-associated risks are typical of a chronic nature, e.g. clinical signs of disease may be seen after several years of intake and exposure. However, some risks and symptoms can be acute, e.g. dermatological reactions of farmers when their skin is exposed to toxic elements in wastewater (Trang et al. 2007; Vuong et al. 2007).

Wastewater in cities is typically together with industrial wastes discharged into the same drains or sewers. Thus wastewater will inevitable contain a range of toxic chemicals such as heavy metals, which may originate from industries like mechanical (Chromium (Cr); Zinc $(\mathrm{Zn})$ ), paint producers and textile (Copper $(\mathrm{Cu})$ ), battery and electrical producers (Arsenic (As); Copper $(\mathrm{Cu})$; Lead $(\mathrm{Pb})$ ). To reduce and prevent adverse health and environmental effects from toxic chemicals, industrial wastes should be adequately pretreated to remove these chemicals or should be treated separately from municipal wastewater. Thus, it is recommended that wastewater used for aquatic food production should not contain significant concentrations of toxic chemicals (WHO 2006). The situation in most South-east 
Asian cities is, however, quite different with wastes from both small and large scale industries being discharged untreated into urban sewers. If such wastewater is used for fish culture and aquatic plant production it can therefore be expected to contain varies toxic chemicals of unknown types and concentrations. The biogeochemistry and fate of toxic chemicals and elements such as heavy metals in the aquatic environment is complex with limited information available on extent, retention and accumulation in the wastewater-fed aquatic production systems and the fish and aquatic plants produce.

This review draws on the up-to-date published research findings on the wastewater-fed aquatic productions in Southeast Asian cities with special focus on heavy metal and other potential toxic elements (PTEs) in the production systems of Hanoi in Vietnam and Phnom Penh in Cambodia. Thus, it adds to information available on problems associated with such toxic elements in traditional soil-based agriculture.

\section{Production and consumption of fish and aquatic plants}

Peri-urban production of fish and aquatic vegetables has gained increasing importance in several Southeast Asian cities because of increasing demands for such products from the growing urban populations and generally high economic returns on crops (van den Berg et al. 2003). Land use has been transformed from traditional rice-based to more profitable vegetable-based systems (Khai et al. 2007). Furthermore, fish and aquatic vegetables are generally perishable and can not be transported or stored for longer periods of time. The production therefore needs to take place in the vicinity to city markets and consumers.

The peri-urban production in Hanoi is a typical example of how wastewater is used for food production and of how the production has shifted from rice culture to vegetable production. In Hanoi, the city sewage, a combination of domestic wastewater and industrial wastewater, is discharged without formal treatment into a drainage system which includes small rivers. Since the 1960 s, these rivers have been the source of wastewater which is pumped and channeled to aquatic ponds and fields. The peri-urban production of vegetables in Hanoi makes up a very important part of the total vegetable supply to the city (van den Berg et al. 2003). Water spinach, which is typically grown in wastewater, is the most commonly consumed vegetable in Hanoi. Out of a total vegetable consumption of $257 \mathrm{~g}$ per capita per day, the consumption of water spinach is about $77 \mathrm{~g}$ (Anh et al. 2004). Fish cultured in wastewater-fed ponds in the Thanh Tri district contributes with about $40 \%$ of the total volume of 8,972 tons of fish produced in the Hanoi area (Hoan and Edwards 2005). Fish are produced in earthen ponds in so-called poly-culture with several species, e.g. mainly Indian and Chinese carps. Two to five stockings and harvests during the year are common, which gives a maximum wastewater exposure time of 10-months for cultivated fish. The consumption of fish in Vietnam is about $53 \mathrm{~g}$ per capita per day (FAO 2003b).

Another type of wastewater exposed food production which takes place in peri-urban areas of Southeast Asia is production in wastewater recipients. Here, the pumping of wastewater is not regulated by the farmer in response to water or nutrients needs. The farmer takes advantage of readily available water and wastewater which is often rich in nutrients. An example of this is seen in the Cheung Ek Lake in Phnom Penh. The lake covers an area of about 3,200 ha and serves as the recipient of most of the wastewater produced in Phnom Penh (Muong 2004; Khov et al. 2006). Up to 22 tons of water spinach is produced in the lake near the wastewater inlet each day (Muong 2004). In Phnom Penh, about $25 \mathrm{~g}$ of water spinach is consumed per capita per day (Abedullah et al. 2002). Fish are not cultured in the Cheung Ek Lake, but occasionally a few wild fish are caught in the 
lake and consumed by the local farmers and household members. The consumption of fish in Cambodia is $70 \mathrm{~g}$ per capita per day (FAO 2003a).

\title{
Fate of PTEs in wastewater-fed food production systems
}

\author{
Sources and characteristics of PTE in wastewater
}

The characteristics of wastewaters can vary significantly due to the extreme variation which can exist in the sources that generates the wastes. PTEs are normally present in relatively low concentrations in conventional irrigation waters but they are not normally included in routine analysis and very little information can be found in the international literature. Zhang et al. (2007) studied peri-urban food production in the Yangtze River Delta region, China and found that the concentrations of the heavy metals $\mathrm{Zn}, \mathrm{Cu}, \mathrm{Cr}$ and $\mathrm{Pb}$ in factorybased wastewater supplied to vegetable production were higher than those in vegetablebased effluent waters suggesting modest pollution of the vegetable-based peri-urban areas.

Khai et al. (2007) presented a $\mathrm{Cu}$ and $\mathrm{Zn}$ balance for a wastewater-fed peri-urban farming system in the Hanoi area. The flows of $\mathrm{Cu}$ and $\mathrm{Zn}$ were quantified over a 1-year period for intensive small-scale aquatic and terrestrial vegetable systems situated in two peri-urban areas of Hanoi. The surpluses of $\mathrm{Cu}$ and $\mathrm{Zn}$ in the system were up to 2.7 and $7.7 \mathrm{~kg} \mathrm{ha}^{-1}$ year $^{-1}$, respectively. This indicated a high risk for contamination with toxic elements and associated transfers through the food chain (Khai et al. 2007).

The major cities in Southeast Asia have millions of inhabitants and a great number of small or large scale industries. Often these cities have no formal wastewater treatment facility and the wastewater is discharged into a drainage system which main purpose is to prevent flooding of the city. This is also the case for the cities of Hanoi and Phnom Penh. Hanoi had a population of about 3.1 million persons in 2004 (HSO 2005). It has been estimated that a total of $458,000 \mathrm{~m}^{3}$ wastewater is generated daily in Hanoi of which $57 \%$ is of industrial origin, $41 \%$ of domestic origin and $2 \%$ is discharged from hospitals. The volume of treated wastewater is less than $5 \%$ of the total volume of wastewater discharged (DOSTE 2003). The wastewater is discharged into small rivers which drain the wastewater out of the city.

The city of Phnom Penh had a population of 1.33 million people in 2008 and a demographic growth of $2.8 \%$ in the period 1998-2008 (JICA 2008). Many of the 750 factories and 4,000 small-scale domestic-based enterprises located in the city are engaged in textile production (Takahashi et al. 2002; PPM 2004). There is no public sewage treatment plants in Phnom Penh and the majority of the industries have been constructed without wastewater treatment facilities (Takahashi et al. 2002). Domestic and industrial wastewater as well as storm water is drained out of the city into Cheung Ek Lake (JICA 1999)

\section{PTE concentrations in aquatic recipients of wastewater}

PTEs in wastewater may be retained in river sediments due to sorption and/or precipitation processes. The rivers may thereby constitute important sinks preventing PTEs from entering wastewater irrigated food production systems. The extent of PTE sorption depends on chemical and physical conditions of the sediment and pore water such as $\mathrm{pH}$, the content of organic carbon and mineral phases, texture, redox conditions, presence of ligands and the total element sediment concentration. Precipitation depends mainly on the concentrations of 
PTEs and inorganic ligands, $\mathrm{pH}$ and redox conditions (Guo et al. 1997; Sauvé et al. 2000; Tyler and Olsson 2001; Holm et al. 2003; Burton et al. 2005).

The total sediment concentrations of selected PTEs in rivers exposed to wastewater have been investigated in India and China (Jain et al. 2005; Huang et al. 2007). Huang et al. (2007) found that the concentrations of $\mathrm{Cu}, \mathrm{Zn}, \mathrm{Pb}$ and $\mathrm{Cr}$ in the sediment along the main river decreased to the background level at about 4.5-5.5 km downstream of the source of origin. Marcussen et al. (2008a, b, 2009) reported ranges of PTE concentrations observed in wastewater receiving rivers in Hanoi, soils at water spinach production sites in Hanoi and sediments of the wastewater receiving lake Cheung Ek Lake in Phnom Penh. These data are compiled and compared with Vietnamese limit values and reported levels from investigations in Thailand and Malaysia (Table 1).

The PTE concentration ranges in soil samples from Hanoi were narrow compared to the range in sediment samples from Phnom Penh (Marcussen et al. 2008a, 2009). In Phnom Penh, a relatively large difference was seen between minimum and maximum sediment concentrations of $\mathrm{Ba}, \mathrm{Cd}, \mathrm{Cu}, \mathrm{Ni}, \mathrm{Pb}, \mathrm{Sb}$ and $\mathrm{Zn}$. The maximum $\mathrm{As}, \mathrm{Be}, \mathrm{Cd}, \mathrm{Ni}, \mathrm{Pb}, \mathrm{Sb}$ and $\mathrm{Tl}$ concentrations in Phnom Penh and Hanoi differed less than a factor two between the two

Table 1 PTE concentration ranges $\left(\mathrm{mg} \mathrm{kg}^{-1}\right.$ d.w.) in soil and sediment from aquatic systems in Southeast Asia with different degree of wastewater (ww) exposure. Limit values and reported levels from non-exposed sites are shown for comparison ( $\mathrm{mg} \mathrm{kg}^{-1}$ d.w.)

\begin{tabular}{|c|c|c|c|c|c|}
\hline & Hanoi & & Phnom Penh ${ }^{\mathrm{c}}$ & $\begin{array}{l}\text { Thailand } d^{\mathrm{d}} \\
\text { Malaysia }^{\mathrm{e}}\end{array}$ & $\begin{array}{l}\text { VN-limit } \\
\text { value }^{f}\end{array}$ \\
\hline System & Flooded soil ${ }^{\mathrm{a}}$ & Rivers $^{\mathrm{b}}$ & Lake & Soil & \\
\hline Produc-tion & Water spinach & None & Water spinach and fishing & Various & \\
\hline ww-exposure ${ }^{g}$ & None to high & High & None to high & None & \\
\hline $\mathrm{N}^{\mathrm{h}}$ & 20 & 54 & 56 & $318 / 241$ & \\
\hline As & $9.1-18.7$ & $17-73$ & $8.89-14.1$ & $30 / 60$ & 12 \\
\hline $\mathrm{Ba}$ & $330-395$ & $393-963$ & $356-688$ & & \\
\hline $\mathrm{Be}$ & $1.66-2.36$ & $1.4-3.0$ & $2.26-2.80$ & & \\
\hline $\mathrm{Cd}$ & $0.333-0.667$ & $<0.88-427$ & $0.07-0.83$ & $0.15 / 0.30$ & 2 \\
\hline $\mathrm{Cr}$ & $68-122$ & $92-281$ & & $80 / 60$ & \\
\hline $\mathrm{Cu}$ & $34.0-62.1$ & $54-240$ & $49.7-149$ & $45 / 50$ & 50 \\
\hline $\mathrm{Ni}$ & $29.9-52.8$ & $38-218$ & $35.3-91.9$ & $45 / 45$ & \\
\hline $\mathrm{Pb}$ & $32.5-67.4$ & $51-363$ & $18.0-99.1$ & $55 / 65$ & 70 \\
\hline $\mathrm{Sb}$ & $1.82-2.86$ & $2.4-12.5$ & $1.73-5.43$ & & \\
\hline $\mathrm{Tl}$ & $0.578-0.765$ & $0.2-1.2$ & $0.86-0.94$ & & \\
\hline $\mathrm{Zn}$ & $91-189$ & $169-1240$ & $149-857$ & $70 / 95$ & 200 \\
\hline
\end{tabular}

\footnotetext{
a Marcussen et al. (2008a)

b Marcussen et al. (2008b)

c Marcussen et al. (2009)

d Zarcinas et al. (2004b)

e Zarcinas et al. (2004a)

f MSTE (2002)

g High wastewater exposure is one to several weekly floodings with untreated wastewater

${ }^{\mathrm{h}} \mathrm{N}$ is total number of replicates analysed
} 
productions systems, though there was a tendency to higher concentrations in Phnom Penh. Copper and Zn sediment concentrations in Cheung Ek Lake in Phnom Penh were a factor 2.4 and 4.5 higher than soil concentrations in Hanoi, respectively.

High PTE concentrations were observed in sediment of the Hanoi rivers that are the main recipients of wastewater in Hanoi. The concentration ranges are given in Table 1. Compared to the PTE concentrations in the Hanoi soils, which receives wastewater from the rivers, the sediment in the rivers had higher concentrations of $\mathrm{As}, \mathrm{Ba}, \mathrm{Cd}, \mathrm{Cr}, \mathrm{Cu}, \mathrm{Ni}$, $\mathrm{Pb}, \mathrm{Sb}$ and $\mathrm{Zn}$ (Marcussen et al. 2008a, b).

Soil and sediment PTE concentrations observed in Hanoi and Phnom Penh were compared to the $95 \%$ percentile for PTEs reported in soils from Malaysia and Thailand as well as Vietnamese limit values for PTEs in agricultural soils. These comparisons were made to evaluate whether the exposure to wastewater have resulted in PTE concentrations above the normal range for the Southeast Asia region and to evaluate if the current PTE concentrations constituted a risk with respect to the vegetable production taking place in soils and sediments.

The Southeast Asian Investigation Levels in Table 1 are based on the 95th percentile value for PTE concentrations in 241 and 318 soils from Malaysia and Thailand, respectively. PTE concentrations above the Investigation Levels indicated that the soil may be polluted, but further investigation will be needed to clarify this.

Arsenic, $\mathrm{Cd}, \mathrm{Cr}, \mathrm{Cu}, \mathrm{Ni}, \mathrm{Pb}, \mathrm{Sb}, \mathrm{Tl}$ and $\mathrm{Zn}$ concentrations in soils from Hanoi were below or only slightly above the Malaysian or Thai Investigation Levels or Vietnamese limit values for agricultural soils. Therefore, the soils do not seem polluted with these PTEs to any major extent. Further, Marcussen et al. (2008a) observed no difference in the overall PTE concentrations between sites of none, low and high wastewater exposure. The Cheung Ek Lake in Phnom Penh had relatively high $\mathrm{Ba}, \mathrm{Cu}, \mathrm{Ni}, \mathrm{Pb}, \mathrm{Sb}$ and $\mathrm{Zn}$ sediment concentrations. The highest concentrations were observed in front of the wastewater inlet and these decreased with increasing distance to the wastewater inlet.

The river sediment in Hanoi had relatively high concentrations of $\mathrm{As}, \mathrm{Ba}, \mathrm{Cd}, \mathrm{Cu}$, $\mathrm{Ni}, \mathrm{Pb}, \mathrm{Sb}$ and $\mathrm{Zn}$. Very high $\mathrm{Cd}$ concentrations with a maximum of $427 \mathrm{mg} \mathrm{kg}^{-1}$ were seen in the sediment of the To Lich River (Table 1; Marcussen et al. 2008b). Cadmium is one of the most toxic elements and the possible release of $\mathrm{Cd}$ from the sediment and transport to the food production systems is therefore of high concern. Marcussen et al. (2008b) recommended that due to the general high PTE concentrations in sediment, in particular the high $\mathrm{Cd}$ concentrations, dredged river sediment should be deposited in areas specially defined for polluted materials where agriculture and aquaculture are prohibited and there is no risk of leaching to ground water sources used for drinking water.

The maximum observed As concentration in sediment from the Hanoi rivers was $73 \mathrm{mg} \mathrm{kg}^{-1} \mathrm{~d}$.w. Some countries in Asia are known to have high geogenic As concentrations. Millions of people suffer from health problems as a result of As intake through drinking water in Taiwan, India and Bangladesh (Chen et al. 1988; Guo et al. 1997; Tsai et al. 1998; Nickson et al. 2000). Part of the observed concentrations may therefore be due to geogenic As, however, the range and distribution of As indicated that As contamination of the river sediments are taking place.

The strong retention of PTEs in river sediments

The results from the studies in Hanoi indicate that PTEs were strongly retained in the sediment of To Lich and Kim Nguu rivers. These rivers had high PTE concentrations in 
sediment, but PTE concentrations in soil from production systems fed with wastewater from the rivers were not elevated (Marcussen et al. 2008a, b).

PTE concentrations determined in pore water of the upper $10 \mathrm{~cm}$ sediment of the Hanoi rivers are presented in Table 2. The observed pore water concentrations of PTEs were low compared to the high PTE concentrations observed in the river sediment (Tables 1, 2).

The distribution of PTEs between the sediment and pore water in the Hanoi rivers can be described by "observed distribution coefficients" $\left(\mathrm{K}_{\mathrm{d} \text {,obs }}\right)$ expressed as the ratio between sediment and pore water concentrations in $\mathrm{mg} \mathrm{kg}^{-1} \mathrm{~d}$.w. and $\mathrm{mg} \mathrm{L}^{-1}$, respectively. The $\mathrm{K}_{\mathrm{d}}$ was termed "observed" since conventional distribution coefficients are determined in systems where sorption is controlling the element distribution. Under these conditions sorption was most likely not the controlling retention mechanism in the Hanoi river sediment. Logarithm to $\mathrm{K}_{\mathrm{d}, \mathrm{obs}}$-values for the Hanoi river sediment are presented in Table 2.

Sauvé et al. (2000) compiled information from more than 70 studies to investigate $\mathrm{K}_{\mathrm{d} \text {,obs }}$-ranges for 13 PTEs in soils. Furthermore, they developed linear regressions between $\log _{10} \mathrm{~K}_{\mathrm{d} \text {,obs }}$-values against $\mathrm{pH}$, soil organic carbon and the total soil element concentration for $\mathrm{Cd}, \mathrm{Cu}, \mathrm{Ni}, \mathrm{Pb}$ and $\mathrm{Zn}$. The $\log _{10} \mathrm{~K}_{\mathrm{d}, \mathrm{obs}}$-values for $\mathrm{Cd}, \mathrm{Cr}, \mathrm{Cu}, \mathrm{Mo}, \mathrm{Pb}$ and $\mathrm{Zn}$ observed for the Hanoi rivers sediment were compared to ranges observed for soils compiled by Sauvé et al. (2000) (Table 2). Ranges for the $\log _{10} \mathrm{~K}_{\mathrm{d}, \mathrm{obs}}$-values for sediment from the Hanoi rivers were high compared to the ranges observed for soils. In addition, the $\log _{10} \mathrm{~K}_{\mathrm{d} \text {,obs }}$-values for the Hanoi river sediment were higher than $\log _{10} \mathrm{~K}_{\mathrm{d}}$-values calculated for the Hanoi river sediment using the linear regressions developed by Sauvé et al. (2000) (Table 2). The high $\log _{10} \mathrm{~K}_{\mathrm{d} \text {,obs }}$-values seen for the sediment show that the rivers had a high PTE retention capacity. Such high $\log _{10} \mathrm{~K}_{\mathrm{d} \text {,obs }}$-values were not likely to be the result of sorption processes and they therefore indicate that the concentrations of $\mathrm{Cd}, \mathrm{Cr}, \mathrm{Cu}, \mathrm{Mo}, \mathrm{Pb}$ and $\mathrm{Zn}$ in the pore water were partly controlled by precipitation processes.

The river sediment was highly anaerobic. Redox potentials ranged from -257 to $-185 \mathrm{mV}$ (Marcussen et al. 2008b). At these redox potentials sulphur, which is a normal constituent of domestic wastewater, will be present as reduced sulphide (Bartlett 1999). Sulphide forms slightly soluble precipitates with the PTEs $\mathrm{Cd}, \mathrm{Cu}, \mathrm{Ni}, \mathrm{Pb}$ and $\mathrm{Zn}$ (Smith

Table 2 Concentration ranges of PTEs in pore water and the logarithm to the observed and calculated ${ }^{\mathrm{a}}$ distribution coefficients $\left(\log _{10} \mathrm{~K}_{\mathrm{d} \text {,obs }}\right)$ for Hanoi rivers and different soils (Sauvé et al. 2000) for comparison

\begin{tabular}{|c|c|c|c|c|}
\hline & Concentration $\mathrm{mg} \mathrm{L}^{-1}$ & $\log _{10} \mathrm{~K}_{\mathrm{d}, \mathrm{obs}}$ & Calculated $\log _{10} \mathrm{~K}_{\mathrm{d}}$ & $\log _{10} \mathrm{~K}_{\mathrm{d}, \mathrm{obs}}$ \\
\hline System & Hanoi rivers & Hanoi rivers & Hanoi rivers & Different soils \\
\hline As & $1.6-36.8$ & $2.75-4.60$ & - & $0.20-5.72$ \\
\hline $\mathrm{Ba}$ & $6.5-2270$ & $2.52-4.98$ & - & $3.15-4.16$ \\
\hline $\mathrm{Cd}$ & $<0.044-0.22$ & $>4.26-5.70$ & $3.0-4.1$ & $-0.36-5.28$ \\
\hline $\mathrm{Cr}$ & $0.24-0.99$ & $5.12-5.90$ & - & $2.10-4.82$ \\
\hline $\mathrm{Cu}$ & $<0.038-0.88$ & $4.96->6.60$ & $3.6-4.0$ & $0.33-4.92$ \\
\hline $\mathrm{Fe}$ & $120-3710$ & $3.97-5.66$ & - & - \\
\hline Mn & $162-1130$ & $2.62-3.78$ & - & - \\
\hline Mo & $0.09-2.00$ & $3.14-4.70$ & - & $1.15-1.72$ \\
\hline $\mathrm{Ni}$ & $0.97-10.1$ & $3.74-4.78$ & $3.1-5.8$ & $0.95-5.41$ \\
\hline $\mathrm{Pb}$ & $0.01-0.86$ & $5.11-7.01$ & $4.1-5.8$ & $1.78-6.36$ \\
\hline $\mathrm{Zn}$ & $0.44-11.0$ & $4.53-6.62$ & $3.0-4.8$ & $0.15-5.51$ \\
\hline
\end{tabular}

${ }^{a}$ calculated $\log _{10} K_{d}$ from linear regression developed by Sauvé et al. (2000) 
and Martell 2003). Sulphide was therefore likely to influence the distribution of these PTEs. PTEs may also have been precipitated as carbonates and hydroxides as the sediment contained a solid carbonate phase and the pore water had a $\mathrm{pH}$ range of 7.4 to 8.1 (Marcussen et al. 2008b). Speciation calculations carried out by Marcussen et al. (2008b) showed that $\mathrm{Cd}, \mathrm{Cu}$ and $\mathrm{Zn}$, but not $\mathrm{Ni}$ concentrations, are well below the level which would be observed in a system controlled only by hydroxide and carbonate precipitation (Marcussen et al. 2008b). This indicates that the distribution of PTEs between the sediment and pore water were controlled by precipitation with sulphide and/or carbonate to a certain level, fixed by the activity of the corresponding anions, carbonate and sulphide. Below this concentration level, the sorption would determine the distribution. Thus, it is believed that the high PTE retention capacity of the Hanoi rivers protected the production systems south of Hanoi from receiving PTEs.

\section{PTEs in fish, edible plants and vegetables}

\section{Concentrations in fish}

Most of the cultured fish species in wastewater are filter feeders living of various types on algae and plankton. Others, e.g. the common carp, are bottom feeders living on benthic organisms. Thus, any accumulation of PTEs in such feed items may lead to increased levels of PTEs in the fish.

Maximum concentrations of $\mathrm{As}, \mathrm{Cd}$ and $\mathrm{Pb}$ in muscle, liver and skin of fish cultivated in wastewater-fed ponds in Hanoi or caught in the Cheung Ek Lake in Phnom Penh are presented in Table 3. Concentrations were generally low and for many samples below the limit of detection (LOD). The highest $\mathrm{Cd}$ and $\mathrm{Pb}$ concentrations in fish from Hanoi were observed in liver tissue of tilapia which had concentrations above the LODs for all replicates (Table 3). The mean $\mathrm{Cd}$ and $\mathrm{Pb}$ concentration in liver samples from tilapia were 0.366 and $0.31 \mathrm{mg} \mathrm{kg}^{-1}$ f.w., respectively (Marcussen et al. 2007). The highest As concentrations in fish from Hanoi were found in skin of tilapia which had a average concentration of $0.15 \mathrm{mg} \mathrm{kg}^{-1}$ f.w. Three out of the 20 replicates had As concentrations below the LOD and were not included in the calculations to obtain an average value.

Arsenic, $\mathrm{Cd}$ and $\mathrm{Pb}$ concentrations in fish from Cheung Ek Lake in Phnom Penh were lower than concentration in fish from Hanoi except for skin of blackskin catfish. Blackskin catfish had high $\mathrm{As}, \mathrm{Cd}$ and $\mathrm{Pb}$ concentrations of $17.3,0.456$ and $0.41 \mathrm{mg} \mathrm{kg}^{-1}$ f.w., respectively.

The tendency of $\mathrm{Cd}$ and $\mathrm{Pb}$ to accumulate in liver and As to accumulate in skin of tilapia as seen in fish from Hanoi are in accordance with observations from other studies. Preferential accumulation of $\mathrm{Cd}$ and $\mathrm{Pb}$ in fish liver were observed by Al-Yousuf et al. (2000); Hollis et al. (2001); Kuznetsova et al. (2002); Canli and Atli (2003); Licata et al. (2005); Dural et al. (2006) and Reynders et al. (2006). Pedlar and Klaverkamp (2002) found that As was significantly accumulated in skin of whitefish (Coregonus clupeformis) fed with a diet containing As. However, As also accumulated in the liver and observed concentrations were higher in the liver than in the skin. However, higher As accumulation in skin than liver of the fresh water fish Tribolodon hakonensis has been observed (Takatsu et al. 1999). Generally, the analyzed fish from Hanoi and Phnom Penh had low As, Cd and $\mathrm{Pb}$ concentrations in the muscle tissue compared to concentrations in other studies (Hollis et al. 2001; Kuznetsova et al. 2002; Canli and Atli 2003; Licata et al. 2005; Dural et al. 2006; Reynders et al. 2006; Pedlar and Klaverkamp 2002). Relatively high $\mathrm{Cd}$ and $\mathrm{Pb}$ 
Table 3 Arsenic, $\mathrm{Cd}$ and $\mathrm{Pb}$ maximum concentrations in muscle, liver and skin tissue of fish from Cheung Ek Lake, Phnom Penh and wastewater-fed ponds in Hanoi ( $\mathrm{mg} \mathrm{kg}^{-1}$ f.w.). The number of replicates for each sample type was 6 in Phnom Penh and 20 in Hanoi. (Marcussen et al. 2007; 2009)

\begin{tabular}{|c|c|c|c|c|c|c|c|c|}
\hline & & & \multicolumn{2}{|l|}{ Muscle } & \multicolumn{2}{|l|}{ Liver } & \multicolumn{2}{|l|}{ Skin } \\
\hline & & & Max & $\begin{array}{l}\text { Below }^{\mathrm{a}} \\
\text { LOD }^{\mathrm{b}}\end{array}$ & Max & $\begin{array}{l}\text { Below } \\
\text { LOD }\end{array}$ & Max & $\begin{array}{l}\text { Below } \\
\text { LOD }\end{array}$ \\
\hline \multirow[t]{9}{*}{ Phnom Penh } & \multirow[t]{3}{*}{ Swamp eel Monopterus albus } & As & $<$ LOD & 6 & $<$ LOD & 6 & 0.02 & 5 \\
\hline & & $\mathrm{Cd}$ & 0.017 & 3 & 0.017 & 4 & 0.028 & 5 \\
\hline & & $\mathrm{Pb}$ & 0.05 & 5 & 0.06 & 4 & $<$ LOD & 6 \\
\hline & \multirow{3}{*}{$\begin{array}{l}\text { Blackskin catfish Clarias } \\
\text { meladerma }\end{array}$} & As & $<$ LOD & 6 & $<$ LOD & 6 & 17.3 & 0 \\
\hline & & $\mathrm{Cd}$ & $<$ LOD & 6 & 0.013 & 4 & 0.456 & 0 \\
\hline & & $\mathrm{Pb}$ & $<\mathrm{LOD}$ & 6 & 0.05 & 5 & 0.41 & 0 \\
\hline & \multirow[t]{3}{*}{ Snakehead Channa striatus } & As & $<\mathrm{LOD}$ & 6 & $<$ LOD & 6 & 0.09 & 4 \\
\hline & & $\mathrm{Cd}$ & $<\mathrm{LOD}$ & 6 & 0.016 & 1 & 0.025 & 3 \\
\hline & & $\mathrm{Pb}$ & $<$ LOD & 6 & $<$ LOD & 6 & 0.07 & 4 \\
\hline \multirow[t]{9}{*}{ Hanoi } & \multirow[t]{3}{*}{ Common carp Cyprinus carpio } & As & 0.12 & 11 & 0.11 & 13 & 0.03 & 14 \\
\hline & & $\mathrm{Cd}$ & 0.079 & 5 & 0.055 & 5 & 0.017 & 11 \\
\hline & & $\mathrm{Pb}$ & 0.04 & 18 & 0.23 & 10 & 0.12 & 16 \\
\hline & \multirow{3}{*}{$\begin{array}{l}\text { Silver carp Hypophthalmichthys } \\
\text { molitrix }\end{array}$} & As & 0.06 & 14 & 0.11 & 14 & 0.03 & 16 \\
\hline & & $\mathrm{Cd}$ & 0.021 & 8 & 0.041 & 7 & 0.015 & 14 \\
\hline & & $\mathrm{Pb}$ & 0.05 & 17 & 0.07 & 14 & 0.06 & 16 \\
\hline & \multirow[t]{3}{*}{ Tilapia Oreochromis niloticus } & As & 0.04 & 15 & 0.10 & 15 & 0.34 & 2 \\
\hline & & $\mathrm{Cd}$ & 0.035 & 9 & 0.841 & 0 & 0.022 & 2 \\
\hline & & $\mathrm{Pb}$ & 0.08 & 15 & 0.68 & 0 & 0.06 & 18 \\
\hline
\end{tabular}

${ }^{a}$ number of samples with concentrations below LOD

${ }^{\mathrm{b}}$ Limit of detection (LOD) was $<0.011,<0.0053$ and $<0.033$ for $\mathrm{As}$, $\mathrm{Cd}$ and $\mathrm{Pb}$, respectively

concentrations were found in liver of tilapia and skin of blackskin catfish, whereas the highest As concentration were found in skin of tilapia and blackskin catfish.

Concentrations in edible plants and vegetables

Concentrations of PTEs observed by Marcussen et al. (2008a, 2009) in water spinach cultivated with none to high wastewater exposure in Hanoi and in Cheung Ek Lake, Phnom Penh are presented in Table 4. Concentration ranges of $\mathrm{As}, \mathrm{Ba}, \mathrm{Be}, \mathrm{Cd}, \mathrm{Cu}, \mathrm{Mn}, \mathrm{Pb}, \mathrm{Tl}$ and $\mathrm{Zn}$ were similar for water spinach cultivated in the two cities. For $\mathrm{Sb}, \mathrm{Ni}$, and especially $\mathrm{Fe}$ the maximum observed concentrations were higher in water spinach from Phnom Penh compared to water spinach from Hanoi (Table 4).

A normal concentration range for PTEs in water spinach grown for human consumption can not be given since PTE concentrations in this plant species only have been determined in a few studies at field conditions (Rai and Sinha 2001; Göthberg et al. 2002; Zarcinas et al. 2004a; Khai et al. 2007). PTE concentrations in water spinach from Hanoi and Phnom Penh were therefore compared to concentrations found in the few existing studies (Table 4). These studies included ranges of PTE concentrations in water spinach grown at conditions ranging from none to high wastewater exposure (Table 4). Water spinach produced in Hanoi and Phnom Penh had similar or only slightly higher PTE concentrations compared to water 
Table 4 PTE concentration ranges ( $\mathrm{mg} \mathrm{kg}^{-1}$ f.w.) in water spinach grown in Asian countries at different degree of pollution or wastewater (ww) exposure. $\mathrm{N}$ indicates the total number of samples analyzed

\begin{tabular}{|c|c|c|c|c|}
\hline & Hanoi $^{\mathrm{a}}$ & Phnom Penh ${ }^{\mathrm{b}}$ & Malaysia $^{\mathrm{c}}$ & Hanoi $^{\mathrm{d}}$ \\
\hline $\mathrm{N}$ & 20 & 56 & 6 & 10 \\
\hline $\begin{array}{l}\text { Pollution } \\
\text { sources }\end{array}$ & $\begin{array}{l}\text { None to high }{ }^{\mathrm{e}} \\
\text { wastewater-exposure }\end{array}$ & $\begin{array}{l}\text { None to high } \\
\text { wastewater-exposure }\end{array}$ & $\begin{array}{l}\text { No major known } \\
\text { pollution sources }\end{array}$ & $\begin{array}{l}\text { High wastewater- } \\
\text { exposure }\end{array}$ \\
\hline As & $0.033-0.139$ & $0.10-0.19$ & $<0.09-0.9$ & \\
\hline $\mathrm{Ba}$ & $1.62-4.81$ & $2.34-5.39$ & & \\
\hline $\mathrm{Be}$ & $0.001-0.002$ & $0.003-0.011$ & & \\
\hline $\mathrm{Cd}$ & $0.008-0.032$ & $<0.004-0.022$ & $0.007-0.055$ & \\
\hline $\mathrm{Cu}$ & $0.51-2.01$ & $0.93-2.95$ & $0.17-1.6$ & $0.18-1.01$ \\
\hline $\mathrm{Fe}$ & $21-39$ & $45-251$ & & \\
\hline Mn & $14.1-55.5$ & $26-43.0$ & & \\
\hline $\mathrm{Ni}$ & $0.047-0.160$ & $0.109-0.412$ & $<0.03-0.28$ & \\
\hline $\mathrm{Pb}$ & $0.104-0.189$ & $0.056-0.206$ & $0.0090-0.10$ & \\
\hline $\mathrm{Sb}$ & $0.006-0.012$ & $<0.0033-0.031$ & & \\
\hline $\mathrm{Tl}$ & $0.008-0.027$ & $0.008-0.014$ & & \\
\hline $\mathrm{Zn}$ & $4.11-6.01$ & $3.39-9.08$ & $2.8-7.7$ & $2.29-2.87$ \\
\hline
\end{tabular}

${ }^{\text {a }}$ Marcussen et al. (2008a)

b Marcussen et al. (2009)

c Zarcinas et al. (2004a)

d Khai et al. (2007)

${ }^{\mathrm{e}}$ High wastewater exposure has been defined as one to several floodings with untreated wastewater

spinach from Malaysia which was cultivated at sites with no known pollution sources (Zarcinas et al. 2004a; Marcussen et al. 2008a, 2009). Khai et al. (2007) investigated the concentrations of $\mathrm{Cu}$ and $\mathrm{Zn}$ in water spinach produced in Bang B village in Hanoi. They found water spinach concentrations of $\mathrm{Cu}$ and $\mathrm{Zn}$ in two production plots ranging from 0.18 to 1.01 and 2.29 to $2.87 \mathrm{mg} \mathrm{kg}^{-1}$ f.w., respectively. In the study by Marcussen et al. (2008a), water spinach $\mathrm{Cu}$ and $\mathrm{Zn}$ concentrations ranged from 0.98 to 1.17 and 5.06 to $5.55 \mathrm{mg} \mathrm{kg}^{-1}$ f.w., respectively. Considering that the standard deviation for $\mathrm{Zn}$ concentrations in water spinach was around $1 \mathrm{mg} \mathrm{kg}^{-1}$ f.w. with 4 replicates collected (Marcussen et al. 2008a), the observed differences in $\mathrm{Cu}$ and $\mathrm{Zn}$ concentrations in water spinach between the two studies are modest.

In conclusion, production of water spinach in wastewater-fed systems in Hanoi and Phnom Penh does not seem to result in increased levels of $\mathrm{As}, \mathrm{Cd}, \mathrm{Cu}, \mathrm{Ni}, \mathrm{Pb}$ and $\mathrm{Zn}$ when compared levels in water spinach from agricultural soils in Malaysia (Zarcinas et al. 2004a; Khai et al. 2007; Marcussen et al. 2008a, 2009).

Clear differences in the overall PTE concentrations could not be seen in water spinach as a result of different levels of wastewater exposure when comparing samples from production systems located in different countries. Since uptake and accumulation of PTEs in edible aquatic plants have been well-documented and plant concentrations have been shown to increase with increasing concentrations of available PTEs in the growth medium, the wastewater exposure was expected to increase the concentrations of PTEs in water spinach (Kashem and Singh 2002; Kumar et al. 2002; Göthberg et al. 2004; Kamal et al. 2004). However, differences in PTE concentrations may be evident, when plants are grown 
in the same production area and the variation in parameters other than in the wastewater is limited. Marcussen et al. (2009) used principal component analysis (PCA) to find the major variations in water spinach concentrations produced in the Cheung Ek Lake, Phnom Penh. The resulting score plot showed that the major variation in water spinach element concentrations was associated with the distance to the wastewater inlets. The elements which differed in concentrations between the wastewater inlets and the lake outlet included the PTEs Be, Cd, Fe, La, Ni, Pb, Sb and $\mathrm{Zn}$.

In the Hanoi study by Marcussen et al. (2008a) no difference could be seen in the PTE concentrations of water spinach cultivated under different degrees of wastewater exposure. A range of factors such as $\mathrm{pH}$, composition and surface characteristics of the soil or sediment, concentrations of complexing ligands, redox conditions and the total soil element concentration could influence the bioavailability of elements and thereby their uptake by water spinach (Sauvé et al. 2000; Tyler and Olsson 2001; Holm et al. 2003; Burton et al. 2005). Age of the plant and the nutritional status could further influence the accumulation of PTEs. Nakanishi et al. (2000) found that the element concentration in water spinach leaves were dependent on the age of the leaf. Göthberg et al. (2004) showed decreasing uptake of $\mathrm{Cd}, \mathrm{Hg}$ and $\mathrm{Pb}$ in water spinach with increasing concentrations of essential plant nutrients. Differences in the physical or chemical conditions in water spinach production systems in Hanoi could therefore have hidden any potential effect of wastewater irrigation on the concentrations of PTEs in water spinach.

The influence of soil $\mathrm{pH}$, organic carbon and total soil element concentrations on the water spinach element concentrations in samples from Hanoi were investigated by linear statistical models by Marcussen et al. (2008a). Soil pH had significant influence on the concentrations of $\mathrm{Mn}$ and $\mathrm{Pb}$ in water spinach. The total soil concentration of $\mathrm{Cr}, \mathrm{Cu}, \mathrm{Pb}$ and $\mathrm{Zn}$ had significant influence on the concentrations of these PTEs in water spinach. However, the parameter with the most influence on the water spinach element concentrations was the soil organic carbon content as it had significant influence on the concentrations of $\mathrm{Ce}, \mathrm{Cr}, \mathrm{Fe}, \mathrm{La}, \mathrm{Li}, \mathrm{Mn}, \mathrm{Nd}, \mathrm{Pr}, \mathrm{Sr}$ and $\mathrm{Y}$ in the water spinach.

In conclusion, elevated concentrations of $\mathrm{Be}, \mathrm{Cd}, \mathrm{Fe}, \mathrm{La}, \mathrm{Ni}, \mathrm{Pb}, \mathrm{Sb}$ and $\mathrm{Zn}$ were found in water spinach grown at the wastewater inlets in Cheung Ek Lake compared to samples collected further away indicating pollution due to wastewater discharge. Though concentrations were elevated, they were not high compared to concentrations seen in water spinach grown without wastewater exposure in Malaysia (Zarcinas et al. 2004a). No elevation of water spinach PTE concentrations occurred in Hanoi due to wastewater exposure.

\section{Food safety risks}

The food safety risks associated with PTEs in aquatic food products cultivated in wastewater-fed systems have so far not been intensively investigated even though concern has been raised that aquatic production systems and products may contain high PTE levels.

The average consumption of foods in Hanoi is about $1 \mathrm{~kg}^{\text {capita }}{ }^{-1}$ day $^{-1}$ (Ali et al. 2006) and the average consumption of water spinach amount to $77.3 \mathrm{~g} \mathrm{capita}^{-1}$ day $^{-1}$ in periurban Hanoi, whereas the consumption of fish is up to $52.9 \mathrm{~g} \mathrm{capita}^{-1}$ day $^{-1}$ (Dey et al. 2005). In Cambodia, water spinach is by far the most commonly consumed leafy vegetable and the total consumption of leafy vegetables has a maximum of $30 \mathrm{~g} \mathrm{capita}^{-1} \mathrm{day}^{-1}$ (Abedullah et al. 2002). Consumption of fresh water fish in Cambodia amounts to $69.4 \mathrm{~g}$ capita $^{-1}$ day $^{-1}$ (FAO 2003a).

The study of water spinach and fish produced in wastewater-fed systems in Hanoi and Cheung Ek Lake in Phnom Penh generally showed low concentrations of PTEs and low 
food safety risks with respect to these elements (Marcussen et al. 2008a, 2009). The risks related to consumption of water spinach and fish grown in wastewater-fed systems in Hanoi and Phnom Penh were determined through a deterministic food safety risk assessment. The intake calculations were based on maximum concentrations observed in water spinach and fish muscle tissue. Furthermore, local data for the average body weights and the consumptions of fish and water spinach were applied (Marcussen et al. 2008a, 2009). The results of the food safety assessments are presented in Table 5. The consumption of water spinach produced in wastewater-fed systems in Hanoi and Phnom Penh would result in an intake of $\mathrm{As}, \mathrm{Cd}, \mathrm{Cu}, \mathrm{Pb}$ and $\mathrm{Zn}$ corresponding to less than $11 \%$ of the tolerable intake set by the Codex Alimentarius Commission and was assessed to be of low risk to human health (Table 5).

The Fe intake from water spinach amounted to 7.9 and $20.5 \%$ of PTI in Hanoi and Phnom Penh, respectively (Table 5). Though Fe is a toxic element in high concentrations, it is also an essential micronutrient. The daily Fe requirement for men and women are 10 and $20 \mathrm{mg} \mathrm{day}{ }^{-1}$, respectively, whereas the PTI is $0.8 \mathrm{mg} \mathrm{kg}^{-1}$ body weight day ${ }^{-1}$. Iron deficiency anaemia is common in Hanoi and Cambodia (NIN 2004; NCN 2002). Therefore, an increased content of $\mathrm{Fe}$ in water spinach is more likely to be an advantage rather than to constitute a food safety risk. The consumption of water spinach would result in a Fe intake around 3.0 and $7.5 \mathrm{mg}$ day $^{-1}$ for residents in Hanoi and Phnom Penh, respectively. Water spinach consumption can therefore be important in the diet of such Fe-deficient populations. The low food safety risks related to consumption of water spinach produced in wastewater-fed systems was in accordance with similar findings in studies conducted in Bangkok. Here, Göthberg et al. (2002) found that 12 and $7.5 \mathrm{~kg}$ fresh water spinach produced in wastewater exposed and non-exposed systems should be consumed by adults before the tolerable intake for $\mathrm{Pb}$ and $\mathrm{Cd}$, respectively, were exceeded. Lead and $\mathrm{Cd}$ intake from other commodities was not included in this calculation.

Intake of $\mathrm{As}, \mathrm{Cd}$ and $\mathrm{Pb}$ through consumption of fish produced in wastewater-fed systems in Hanoi and Phnom Penh amounts to less than 9\% of PTI set by the Codex Alimentarius Commission and is assessed to constitute low food safety risk (Table 5). However, consumption of liver and skin from some fish should be avoided (Marcussen et al. 2008a, 2009). Few other studies have investigated the accumulation of PTEs in wastewaterfed fish. However, Shereif and Mancy (1995) found $\mathrm{Cd}$ and $\mathrm{Pb}$ concentrations above the limit

Table 5 Intake of PTEs in percent $(\%)^{\mathrm{a}}$ of the provisional tolerable intake (PTI) set by the Codex Alimentarius Commission ${ }^{\mathrm{b}}$

\begin{tabular}{|c|c|c|c|c|}
\hline & \multicolumn{2}{|c|}{ Water spinach } & \multicolumn{2}{|l|}{ Fish } \\
\hline & Hanoi & Phnom Penh & Hanoi & Phnom Penh \\
\hline As & 10.7 & 5.7 & 6.6 & $<0.8$ \\
\hline $\mathrm{Cd}$ & 5.2 & 1.4 & 8.7 & 2.6 \\
\hline $\mathrm{Cu}$ & 0.6 & 0.4 & - & - \\
\hline $\mathrm{Fe}$ & 7.9 & 20.5 & - & - \\
\hline $\mathrm{Pb}$ & 8.5 & 3.8 & 2.5 & 2.1 \\
\hline $\mathrm{Zn}$ & 1.0 & 0.6 & - & - \\
\hline
\end{tabular}

${ }^{\text {a }}$ based on the maximum PTE concentrations determined in water spinach and fish, the average body weight and the average consumption in the Hanoi and Phnom Penh

b FAO/WHO (2003) 
value established by the European Commission of 0.05 and $0.2 \mathrm{mg} \mathrm{kg}^{-1}$, respectively in muscle of fish exposed to untreated municipal waste and agricultural run-off. On the other hand were concentrations in wild-caught fish from wastewater receiving rivers not found to constitute a food safety problem (Al-Ogaily et al. 1999; Bosnir et al. 2003).

\section{Conclusion}

Use of untreated wastewater for agriculture and aquaculture is widespread around the major cities in Southeast Asia. In Hanoi and Phnom Penh, wastewater is discharged untreated into sewage systems and rivers which supply aquatic production systems, i.e. water spinach and fish. Based on a review of published concentrations of PTEs in water spinach, fish, soil and sediment of the food production systems, in connected rivers as well as assessments of risks to food safety with respect to PTE concentrations, the following main conclusions can be made.

Sediments in the wastewater exposed rivers of Hanoi were polluted with PTEs, in particular with Cadmium (Cd). Most likely due to precipitation of PTEs as sulphides, the river sediment had a high retention capacity for PTEs. The high retention capacity of the river sediment prevents PTEs to be transferred to the aquatic production systems in Hanoi. Soils from Hanoi showed no significant PTE accumulation when originating from sites of high or low wastewater exposure as compared with sites not exposed to wastewater. Sediment from Cheung Ek Lake in Phnom Penh had elevated concentrations of some PTEs at the inlets of wastewater compared to the lake outlet and the control site.

Maximum PTE concentrations in water spinach produced in Hanoi and Phnom Penh were within or only slightly above the concentration ranges observed for water spinach grown in agricultural soils not exposed to wastewater. However, water spinach from Cheung Ek Lake grown near the wastewater inlets had elevated concentrations of some PTEs when compared to concentrations in water spinach harvested at the lake outlet and at the control site.

PTE concentrations in muscle, skin and liver of fish grown in wastewater-fed systems in Hanoi and Phnom were low and consumption resulted in an estimated intake of PTEs amounting to less than $9 \%$ of the tolerable intake according to guidelines of the FAO. However, mean PTE concentrations in liver and skin of some fish were high.

This review shows that use of wastewater for production of water spinach and fish in Hanoi and Phnom Penh are associated with few if any food safety risks with respect to PTEs. Furthermore, the wastewater serves as a low cost source of both water and nutrients. Wastewater use therefore has high benefits for the economy of farmers and the productivity of the peri-urban aquatic food production systems. However, farmers are directly exposed to the PTEs from wastewater as they work with little protective measures and have legs and arms submerged in the water for several hours a day which may result in dermatological and other health problems. It is also of some concern that river sediment contains high concentrations of PTEs and there is a risk that PTEs are released both in the rivers and after dredging. Sustainable solutions must be found to manage the accumulation and possible release of PTEs in sediment which may be applied to agricultural fields.

Acknowledgements The study was carried out with financial support from the EC-INCO-DEV funded project 'Production in Aquatic Peri-Urban Systems in Southeast Asia' (PAPUSSA; http://www.papussa.org); the Danish International Development Agency (Danida), Danish Ministry of Foreign Affairs, projects number 104.Dan.8.-887 "Metal accumulation and food safety in wastewater-fed aquatic production systems in Cambodia and Vietnam" and the research capacity building project "Sanitary Aspects of Drinking Water and Wastewater Reuse in Vietnam", grant no.104.Dan.8.L.; and the Strategic Water Research Initiative (ViVa), Faculty of Life Sciences, University of Copenhagen. 
Open Access This article is distributed under the terms of the Creative Commons Attribution Noncommercial License which permits any noncommercial use, distribution, and reproduction in any medium, provided the original author(s) and source are credited.

\section{References}

Abedullah, Sokhom S, Farooq U (2002) Kingdom of Cambodia. In: Ali M (ed) The vegetable sector in Indochina Countries: farm and household perspectives on poverty alleviation, Technical Bulletin No. 27, Asian Regional Centre (ARC), Asian Vegetable Research and Development Center (AVRDC), Thailand, pp 32-76

Ali M, Quan NT, Nam NV (2006) An analysis of food demand patterns in Hanoi: predicting the structural and qualitative changes. Technical Bulletin No. 35. AVRDC publication No. 06-671. The World Vegetable Center (AVRDC), Shunhua

Al-Ogaily SM, Al-Harbi AM, Ali A (1999) Impact of sewage wastes of the heavy metal content of water, soil, plants and fish in Wadi Hanifah Stream. Arab Gulf J Sci Res 17:382-395

Al-Yousuf MH, El-Shahawi MS, Al-Ghais SM (2000) Trace metals in liver, skin and muscle of Lethrinus lentjan fish species in relation to body length and sex. Sci Total Environ 256:87-94

Bartlett RJ (1999) Characterizing soil redox behaviour. In: Sparks DL (ed) Soil physical chemistry, 2nd edn. CRC, Boca Raton, pp 371-397

Bosnir J, Puntaric D, Skes I, Klaric M, Simic S, Zoric I, Galic R (2003) Toxic metals in freshwater fish from the Zagreb area as indicators of environmental pollution. Coll Antropol 27:31-39

Burton ED, Phillips IR, Hawker DW (2005) Geochemical partitioning of copper, lead and zinc in benthic, estuarine sediment profiles. J Environ Qual 34:263-273

Canli M, Atli G (2003) The relationships between heavy metal (Cd, Cr, Cu, Fe, Pb, Zn) levels and the size of six Mediterranean fish species. Environ Pollut 121:129-136

Chen CJ, Kug TL, Wu MM (1988) Arsenic and cancers. Lancet 1:414-415

Dey MM, Rab MA, Paraguas FJ, Piumsombun S, Bhatta R, Alam MF, Ahmed M (2005) Fish consumption and food security: a disaggregated analysis by types of fish and classes of consumers in selected Asian countries. Aquac Econ Manag 9:89-111

DOSTE (2003) General planning of environment in Hanoi in the period 2001-2010, Vol.1.The real environmental situation of Hanoi. Department of Science, Technology and Environment (DOSTE), Peoples Committee of Hanoi, Hanoi in Vietnamese

Dural M, Göksu MZL, Özak AA, Derici B (2006) Bioaccumulation of some heavy metals in different tissues of Dicentrarchus labrax L, 1758, Sparus aurata L, 1758 and Mugil cephalus L, 1758 from the Camlik lagoon of the eastern cost of Mediterranean (Turkey). Environ Monit Assess 118:65-74

FAO (2003a) Food balance sheet Cambodia, 2003. FAO Statistical Division, Food and Agriculture Organization (FAO), http://faostat.fao.org Downloaded May 2007

FAO (2003b) Food balance sheet Vietnam, 2003. FAO Statistical Division, Food and Agriculture Organization (FAO), http://faostat.fao.org Downloaded November 2006

FAO/WHO (2003) Joint FAO/WHO food standards programme, Codex committee on food additives and contaminants, Thirty-sixth session, Rotterdam, The Netherlands, 22-26 March 2004

Göthberg A, Greger M, Bengtsson B (2002) Accumulation of heavy metals in water spinach (Ipomoea aquatica) cultivated in the Bangkok region, Thailand. Environ Toxicol Chem 21:1943-1939

Göthberg A, Greger M, Holm K, Bengtsson B (2004) Influence of nutrient levels on uptake and effects of mercury, cadmium, and lead in water spinach. J Environ Qual 33:1247-1255

Guo T, DeLaune RD, Patrick WH (1997) The influence of sediment redox chemistry on chemically active forms of arsenic, cadmium, chromium, and zinc in estuarine sediment. Environ Int 23:305-316

Hoan VQ, Edwards P (2005) Wastewater reuse through urban aquaculture in Hanoi, Vietnam: status and prospects. In: Costa-Pierce B, Desbonnet A, Edwards P, Baker D (eds) Urban aquaculture. CABI International, Wallingford, pp 103-117

Hollis L, Hogstrand C, Wood CM (2001) Tissue-specific cadmium accumulation, metallothionein induction, and tissue zinc and copper levels during chronic sublethal cadmium exposure in juvenile rainbow trout. Arch Environ Contam Toxicol 41:468-474

Holm PE, Rootzén H, Borggaard OK, Møberg JP, Christensen TH (2003) Correlation of cadmium distribution coefficients to soil characteristics. J Environ Qual 32:138-145

HSO (2005) Hanoi statistical yearbook, Hanoi Statistical Office (HSO) 
Huang B, Zhao Y, Shi X, Yu D, Zhao Y, Sun W, Wang H, Oborn I (2007) Source identification and spatial variability of nitrogen, phosphorus, and selected heavy metals in surface water and sediment in the riverine systems of a peri-urban interface. J Environ Sci Health, Part A. Toxic/Hazard Substances and Environ Eng 42:371-380

Jain CK, Singhal DC, Sharma MK (2005) Metal pollution assessment of sediment and water in the river Hindon, India. Environ Monit Assess 105:193-207

JICA (1999) The study on drainage improvement and flood control, Municipality of Phnom Penh, Volume 2, Japan International Cooperation Agency (JICA)

Kamal M, Ghaly AE, Mahmoud N, Côté R (2004) Phytoaccumulation of heavy metals by aquatic plants. Environ Int 29:1029-1039

Kashem MA, Singh BR (2002) The effect of fertilizer additions of the solubility and plant-availability of Cd, $\mathrm{Ni}$ and $\mathrm{Zn}$ in soil. Nutr Cycl Agroecosyst 62:287-296

Khai NM, Ha PQ, Öborn I (2007) Nutrint flows in small-scale peri-urban vegetable farming systems in Southeast Asia-A case study in Hanoi. Agric Ecosyst Environ 122:192-202

Khov K, Little D, Leschen W (2006) Household baseline and monitoring survey report on production in aquatic peri-urban systems in Phnom Penh, Cambodia. Production in Aquatic Peri-urban Systems in Southeast Asia (PAPUSSA), www.papussa.org Downloaded January 2007

Kumar M, Chikara S, Chand MK, Bhatnager AK (2002) Accumulation of lead, cadmium, zinc, and copper in the edible aquatic plants Trapa bispinosa Roxb. and Nelumbo nucifera Gaertn. Bull Environ Contam Toxicol 69:649-654

Kuznetsova AI, Zarubina OV, Leonova GA (2002) Comparison of $\mathrm{Zn}, \mathrm{Cu}, \mathrm{Pb}, \mathrm{Ni}, \mathrm{Cr}$, Sn, Mo concentrations in tissues of fish (roach and perch) from Lake Baikal and Bratsk Reservoir, Russia. Environ Geochem Health 24:205-213

Leschen W, Little D, Bunting S (2005) Urban aquatic production. Editorial. Urban Agriculture Magazine 14:1-7

Licata P, Trombetta D, Cristani M, Naccari C, Martino D, Calò M, Naccari F (2005) Heavy metal in liver and muscle of bluefin tuna (Thunnus thynnus) caught in the straits of Messina (Sicily, Italy). Environ Monit Assess 107:239-248

Marcussen H, Holm PE, Dalsgaard A (2007) Food safety aspects of toxic element accumulation in fish from wastewater-fed ponds in Hanoi, Vietnam. Trop Med Int Health 12(Supp. 2):34-39

Marcussen H, Joergensen K, Holm PE, Brocca D, Simmons RW, Dalsgaard A (2008a) Element contents and food safety of water spinach (Ipomoea aquatica Forssk.) cultivated with wastewater in Hanoi, Vietnam. Environ Monit Assess 139:77-91

Marcussen H, Dalsgaard A, Holm PE (2008b) Content, distribution and fate of 33 elements in sediments of rivers receiving wastewater in Hanoi, Vietnam. Environ Pollut 155:41-51

Marcussen H, Dalsgaard A, Holm PE (2009) Element concentrations in water spinach (Ipomoea aquatica Forssk.), fish and sediment from a wetland production system that receives wastewater from Phnom Penh, Cambodia. J Environ Sci Health Part A 44:67-77

MSTE (2002) Vietnam Standard TCVN 7209:2002. Soil quality, Ministry of Science, Technology and Environment (MSTE), Vietnam in Vietnamese

Muong S (2004) Avoiding adverse health impacts from contaminated vegetables: options for three Wetlands in Phnom Penh, Cambodia. Economy and Environment Program for Southeast Asia (EEPSEA), www. eepsea.org, Downloaded November 2004

Nakanishi TM, Furukawa J, Ueoka S (2000) Kinetics of transition elements profile during the life cycle of morning-glory. J Radioanal Nucl Chem 244:289-293

NCN (2002) Cambodia Nutrition Investment Plan (CNIP) 2003-2007. National Council for Nutrition $(\mathrm{NCN})$, Ministry of Planning, Cambodia, pp 9-16

Nickson RT, McArthur JM, Ravenscroft P, Burgess WG, Ahmed KM (2000) Mechanism of arsenic release to groundwater, Bangladesh and West Bengal. Appl Geochem 15:403-413

NIN (2004) Hanoi annual report, 2004. National Institute of Nutrition (NIN), Hanoi in Vietnamese

Pedlar RM, Klaverkamp JF (2002) Accumulation and distribution of dietary arsenic in lake whitefish (Coregonus clupeaformis). Aquat Toxicol 57:153-166

PPM (2004) Master plan: strategic orientations. Phnom Penh Municipality (PPM), www.phnompenh.gov.kh, Downloaded May 2006

Rai UN, Sinha S (2001) Distribution of metals in aquatic edible plants: Trapa natans (Roxb.) Makino and Ipomoea aquatica Forsk. Environ Monit Assess 70:241-252

Reynders H, Van Campenhout K, Bervoets L, De Coen WM, Blust R (2006) Dynamics of cadmium accumulation and effects in common carp (Cyprinus carpio) during simultaneous exposure to water and food (Tubifex turbifex). Environ Toxicol Chem 25:1558-1567

Sauvé S, Hendershot W, Allen HE (2000) Solid-solution partitioning of metals in contaminated soils: dependence on $\mathrm{pH}$, total metal burden, and organic matter. Environ Sci Technol 34:1125-1131 
Shereif MM, Mancy KH (1995) Organicchlorine pesticides and heavy metals in fish reared in treated sewage effluents and fish grown in farms using polluted surface waters in Egypt. Water Sci Technol 32:153-161

Smith RM, Martell AE (2003) NIST Standard reference database 46. NIST Critically selected stability constants of metal complexes database. Version 7.0 for Windows. U.S. Department of Commerce, Technology Administration, National Institute of Standards and Technology

Takahashi Y, Doi R, Endomoto H (2002) Section 7. The environment. In: The Kingdom of Cambodia-From reconstruction to sustainable development- JICA Country Study for Japan's ODA. Institute for International Cooperation, Japan International Cooperation Agency (JICA), pp 278-315

Takatsu A, Kuroiwa T, Uchiumi A (1999) Arsenic accumulation in organs of the fresh water fish Tribolodon hakonensis. J Trace Elem Med Biol 13:176-179

Trang DT, van der Hoek W, Tuan ND, Cam PD, Viet VH, Luu DD, Konradsen F, Dalsgaard A (2007) Skin disease as an occupational health risk for farmers using wastewater in Nam Dinh, Vietnam. Tropical Med Int Health 12(Supp. 2):50-57

Tsai SM, Wang TN, Ko YC (1998) Cancer mortality trends in a Blackfoot disease endemic community of Taiwan following water source replacement. J Toxicol Environ Health Part A 55:389-404

Tyler G, Olsson T (2001) Concentrations of 60 elements in the soil solution as related to the soil acidity. Eur J Soil Sci 52:151-165

van den Berg LM, van Wijk MS, Hoi PV (2003) The transformation of agriculture and rural life downstream of Hanoi. Environ Urban 15:35-52

Vuong TA, van der Hoek W, Ersbøll AK, Thuong NT, Tuan ND, Cam PD, Dalsgaard A (2007) Dermatitis among farmers engaged in peri-urban aquatic food production in Hanoi, Vietnam. Tropical Med Int Health 12(Supp. 2):58-64

WHO (2006) Guidelines for the safe use of wastewater, excreta and greywater: wastewater and excreta use in aquaculture (volume 3). The World Health Organization, Geneva

Zarcinas BA, Ishak CH, McLaughlin MJ, Cozens G (2004a) Heavy metals in soils and crops in Southeast Asia. 1. Peninsular Malaysia. Environ Geochem Health 26:343-357

Zarcinas BA, Ishak CH, McLaughlin MJ, Cozens G (2004b) Heavy metals in soils and crops in Southeast Asia. 2. Thailand. Environ Geochem Health 26:343-357

Zhang QL, Shi XZ, Huang B, Yu DS, Öborn I, Blombäck K, Wang HJ, Pagella TF, Sinclair FL (2007) Surface water quality of factory-based and vegetable-based peri-urban areas in the Yangtze River Delta region, China. Catena 69:57-64 